\title{
Effect of a 10-week yoga programme on the quality of life of women after breast cancer surgery
}

\author{
Aleksandra Andysz ${ }^{1}$, Dorota Merecz ${ }^{1}$, Aleksandra Wójcik ${ }^{1}$, Beata Świątkowska², Kamilla Sierocka ${ }^{3}$, \\ Anna Najder ${ }^{1}$
}

${ }^{1}$ Department of Occupational Psychology, Nofer Institute of Occupational Medicine, Lodz, Poland ${ }^{2}$ Department of Environmental Epidemiology, Nofer Institute of Occupational Medicine, Lodz, Poland ${ }^{3}$ Certified lyengar Yoga teacher, Introductory I

\begin{abstract}
'
Aim of the study: The following research is aimed at determining the effect of yoga on the quality of life of women after breast cancer surgery.

Material and methods: A 10-week yoga programme included 90-minute yoga lessons once a week. To estimate the quality of life, questionnaires developed by the European Organisation for Research and Treatment of Cancer (QLQ-C30 and QLQ-BR23) were used. An experimental group consisted of 12 women who practised yoga, a control group - of 16 women who did not. Between groups there were no differences in age, time from operation and characteristics associated with disease, treatment and participation in rehabilitation.

Results: Our results revealed an improvement of general health and quality of life, physical and social functioning as well as a reduction of difficulties in daily activities among exercising women. Also their future prospects enhanced - they worried less about their health than they used to before participating in the programme. As compared to baseline, among exercising women, fatigue, dyspnoea and discomfort (pain, swelling, sensitivity) in the arm and breast on the operated side decreased.

Conclusions: Participation in the exercising programme resulted in an improvement of physical functioning, reduction of fatigue, dyspnoea, and discomfort in the area of the breast and arm on the operated side. Based on our results and those obtained in foreign studies, we conclude that rehabilitation with the use of yoga practice improves the quality of life of the patients after breast cancer surgery. However, we recommend further research on this issue in Poland.
\end{abstract}

Key words: yoga, rehabilitation, quality of life, breast cancer, mastectomy.

\section{Introduction}

The experience of cancer is devastating for many people who suffer from that. Diagnosis, painful treatment, rehabilitation and sense of uncertainty associated with the risk of recurrence significantly influence the quality of life of people suffering from cancer as well as their close friends and relatives. The quality of life of such patients have been widely investigated so far. Extant studies documented how devastating the diagnosis and treatment of cancer could be and how long the sense of loss in various aspects of life can persist [1, 2].

Breast cancer is the most common malignant tumour among women in the world. Over one million new cases are reported every year, what amounts to approximately $22.8 \%$ of all registered malignant tumours. Between 1963 and 2011, the number of newly diagnosed breast cancers among Polish women increased six-fold (from 2476 to 16534 cases) [3]. The prevalence of breast cancers in 2025 is predicted to be more than $50 \%$ higher than in 2006 [4].

Unfortunately, although Poland is one of the countries with a moderate level of breast cancer morbidity, we have observed a constantly increasing trend of mortality because of this disease in recent decades. In 2011, five thousand deaths from breast cancer were registered (three times more than in 1963) [3]. This results to a great extent from the fact that in Poland breast cancer is usually diagnosed only when it reaches an advanced stage while in Western countries its curability is twice as high as compared to our country mostly due to broadly defined prevention strategies, including education [5].

Currently, we recognize environmental aspects affecting the development of breast cancer (e.g. lifestyle). However, family and genetic risk factors still constitute a significant probability of disease, so it is not always possible to avoid cancer. Therefore, actions aimed at lim- 
iting the consequences of this disease and supporting patients' recovery and return to their normal life activity are of great importance. Psychophysical rehabilitation plays a pivotal role in this process and should make an integral part of breast cancer treatment. Such rehabilitation includes restoring the state of health comparable to the one from the period before the disease as well as satisfactory psychosocial functioning. Having undergone a surgery and left the hospital, patients should continue the rehabilitation with the help of specialists and on their own - following their doctors' instructions. Unfortunately, still not all Polish breast cancer patients are provided with comprehensive support during the rehabilitation process.

The beginnings of scientific interest in yoga as a rehabilitation method date back to the 1950's as regards Western countries, and to the 1980's as far as Poland is concerned [6]. Considered as a system of physical exercises, yoga's advantage is the diversity of its intensity - it can be adjusted to an individual participant's possibilities, regardless of his or her physical condition, diseases or injuries. Yoga's impact on well-being of healthy people as well as those suffering from chronic diseases (including patients with diagnosed breast cancer) has been widely documented [7], and the interest in this issue is constantly growing.

Yoga is recommended especially for patients after mastectomy because it offers exercises that make particular parts of the body more flexible but it has also a local effect - such exercises gently stretch the areas of post-surgical adhesions, and make the shoulder girdle and muscles around the armpits stronger and more efficient. Yoga also corrects postural defects. Radical operation such as mastectomy results in unfavourable changes in body posture and trunk static. These changes relate among others to the position of shoulder blades, shoulders, or pelvis, differences in waist triangles width or trunk angle [8]. They may result from muscles damage, pain related to post-operative cicatrix or tissue fibrosis caused by radiotherapy [9].

Lymphedema of the upper extremities can appear as a complication of surgical treatment of breast cancer and it affects $10-30 \%$ of patients [10]. Well-chosen exercises make lymph flow more efficiently and thus, they decrease the risk of lymphedema occurrence, or reduce the severity of the existing one [10]. Yoga poses (asanas), including trunk twists, massage, purify and regenerate organs of the abdominal cavity. Supported back bends, in turn, open the chest, improve the way heart and lungs work, stimulate the digestive system and increase spine mobility. Yoga practice involves also extended breathing techniques (pranayama) that energize, relax and enhance breathing efficiency.

Yoga programmes described in the extant literature addressed to breast cancer patients were most often based on Hatha Yoga according to B.K.S. lyengar meth- od. All those programmes involved muscles stretching, breathing exercises and relaxation. The compilation of exercises resulted in a noticeable improvement of musculoskeletal system efficiency, flexibility and strength of muscles, and state of balance. The majority of exercises were performed in supported seated or reclining positions [11, 12]. During such classes, participants made use of props typical for Hatha Yoga according to lyengar's method blankets, straps, bolsters or wooden blocks. The abovementioned programmes differed in the length of lessons or the whole series/programmes, which lasted from 6 to 24 weeks $[13,14]$. Some of participants practiced yoga 60 minutes a day [15] while others exercised for $75 \mathrm{~min}$ utes once a week [16] or 90 minutes twice a week [17].

Most of women who participated in such exercises reported an improvement in their physical, emotional and spiritual functioning. They felt greater peace of mind and hope as well as relief for symptoms associated with treatment. It was also observed that social support from other women suffering from the same disease and having similar experience enhanced the treatment process [18]. Performing exercises based on the yoga method reduced also somatic symptoms, namely they decreased the frequency and intensity of nausea and vomiting caused by chemotherapy [15]. Extant research documented that day by day women experienced significantly less pain and at the same time, they felt more lively, accepting and relaxed [19]. Numerous studies on exercising patients indicated reduction of fatigue caused by the disease and treatment $[19,20]$. They also revealed that in comparison with those who did not exercise, women who took physical exercises functioned better socially and emotionally [21]. It was also observed that yoga decreased depression, stress or anxiety associated with cancer [7, 22]. Authors of the literature review on yoga classes dedicated to women with breast cancer indicated that such programmes' impact on the general quality of life can be described as neutral or positive [23].

\section{Aim of the study}

Our rationale to investigate the issue was the need for empirical assessment of the effectiveness of yoga among Polish breast cancer patients. Despite its popularity abroad, the subject of the influence of yoga on functioning of patients after mastectomy and other breast surgeries have not been undertaken in Poland so far. Our research was aimed to fill this gap.

We raised two research questions:

1. Does a programme of rehabilitation classes based on yoga influence the quality of life of women after breast surgery?

2. Does the quality of life differ between women after breast surgery who practiced yoga and those who did not? 
Considering the previous findings, we hypothesized that participating in yoga practice would have a positive impact on the general quality of life as well as emotional and physical functioning of the participants. We also assumed that exercising women would perceive the reduction of fatigue, improvement of body image as well as mobility and strength of the arm on the operated breast side.

\section{Material and methods}

The programme called "Baba Joga kontra rak" (Baba Joga vs. cancer) lasted from April to June 2013. The inspiration for the initiative were yoga classes that have been conducted for 12 years by the Unicorn Cancer Care in Cracow. In order to recruit the participants, a short information campaign about the programme was run by Łódzka Fundacja "Kocham Życie" (NGO foundation from Lodz), in the local supplement to the daily newspaper "Gazeta Wyborcza", as well as via Facebook. The information about the programme was also spread through the associations gathering Amazons in the Lodz voivodeship. The inclusion criteria included women aged 18-80, with stage I to III of breast cancer who underwent breast surgery. To collect data, we used selfadministered questionnaires twice: at the beginning of the project (before the first class) and after 10 weeks of the programme.

The first stage of the study involved 56 women who had come forward in response to the campaign. They were informed about the study aims as well as of anonymity and participation being voluntary. The experimental group consisted of women who participated in the exercising programme. The participants of this group had never practiced yoga before. The control group involved women who were informed about the programme, but decided not to take part in the exercises - they only completed the questionnaires. From the statistical analysis we excluded incomplete questionnaires, those that were filled once only and the data from the participants who attended yoga classes less than four times. Eventually, the experimental group included 12 women and the control group - 16 women.

There were no differences in age, time since the operation, characteristics associated with the disease, its treatment and participation in rehabilitation between women who practised yoga during the programme and those who did not (Table I). The women in the two groups did not differ as regards their education level, self-assessed level of income or physical activity.

Women, who decided to participate in the programme, paid a fee - the price was low as compared to commercial classes and amounted to approximately $30 \%$ of its market value.

Classes took place once a week and lasted 90 minutes and were held in one of the local fitness clubs. Ex- ercises were prepared by a certified and experienced yoga instructor who was the author of the programme. Each class combined poses (asanas), breathing exercises (pranayama), and relaxation. The props typical of lyengar's Hatha Yoga (bolsters, wooden blocks, straps) were used. All asanas were adjusted to participants' specific needs considering the fact that women after breast surgery may suffer from pain in the body areas where surgical interventions were applied, their arms' muscles are weakened and their mobility is decreased.

Exemplary sequence of asanas included: 1) Supta Badha Konasana, 2) Adho Mukha Virasana; standing poses: 3) Tadasana with supported back, 4) Vrksasana, 5) Trikonasana, 6-7) Virabadhrasana I and II; seated poses: 8) Bharadvajasana with a hand supported on the wall or a block, 9) Janu Sirsasana with the use of strap, 10) twist in Upavista Konasana, 11) Upavista Konasana with the use of a strap; lying poses: 12-13) Supta Padangusthasana I and II, 14) Viparita Karani with hips supported on a bolster and legs supported on the wall; relaxation exercises: 15) Pranayama lying or sitting (Ujjayi or Viloma breath), 16) Savasana. To become acquainted with the way the above-mentioned poses look like, please refer to B.K.S. Iyengar's 'Light on Yoga'.

The quality of life was measured with the use of a questionnaire developed by the European Organisation for Research and Treatment of Cancer (EORTC). It is designed to study oncological patients in different stages of disease and subjected to various forms of therapy [24]. It consists of a 30-item basic module (QLQ-C30, version 3.0) addressed to all oncological patients and a supplementary 23-item module for patients with breast cancer (QLQ-BR23). In the following research, we used Polish adaptations of the above questionnaires provided by the EORTC.

The basic module consists of: global health status and quality of life scale, five scales concerning functioning and symptom scales including items relating to occurrence, intensity and upset caused by fatigue, nausea and vomiting, pain, dyspnoea, insomnia, appetite loss, constipation, diarrhoea, and financial difficulties. The module for breast cancer patients includes four scales considering body image, sexual functioning, sexual enjoyment and future perspective and four symptom scales (Systematic therapy side effects, Arm and Breast symptoms and Upset by hair loss).

The participants assessed their functioning and symptoms on a 4-score scale including not at all, a little, quite $a$ bit and very much. The general health state and quality of life were assessed with the use of a 7-score scale from very poor to excellent. To analyse the acquired data, we used standardized results from particular scales [25]. Considering the functioning scales and general health status and quality of life, the higher the score, the better functioning or health state/quality of life while in symptoms scales - the higher level of problems. 
Tab. I. Distribution of demographic variables associated with the disease and treatment in both groups and the significance of differences estimated with the use of Mann-Whitney test and Pearson's $\chi^{2}$

\begin{tabular}{|c|c|c|c|}
\hline & Exercising & Non-exercising & $\begin{array}{c}\text { Significance of } \\
\text { differences (two-tailed) }\end{array}$ \\
\hline Age in years, $M \pm S D$ (Min-Max) & $54.8 \pm 7.4(43.2-66.7)$ & $58.6 \pm 10.8(38.9-76.5)$ & NS \\
\hline Years from operation, $M \pm S D$ (Min-Max) & $5.5 \pm 4.2(2.0-15.1)$ & $7.6 \pm 6.4(0.5-23.7)$ & NS \\
\hline \multicolumn{3}{|l|}{ Cancer location, $n(\%)$} & \multirow{4}{*}{ NS } \\
\hline Left breast & $5(42)$ & $11(69)$ & \\
\hline Right breast & $6(50)$ & $5(31)$ & \\
\hline Both breasts & $1(8)$ & - & \\
\hline \multicolumn{3}{|l|}{ Type of operation, $n(\%)$} & \multirow{4}{*}{ NS } \\
\hline Breast conserving surgery & $3(25)$ & $3(19)$ & \\
\hline Mastectomy & $9(75)$ & $13(81)$ & \\
\hline Lymph node dissection* & $9(75)$ & $14(87)$ & \\
\hline \multicolumn{3}{|l|}{ Type of treatment, $n$ (\%) } & \multirow{7}{*}{ NS } \\
\hline Chemotherapy & $3(25)$ & $5(31)$ & \\
\hline Hormone therapy & - & $2(13)$ & \\
\hline Chemotherapy, hormone therapy & $3(25)$ & $5(31)$ & \\
\hline Radiotherapy, hormone therapy & $2(17)$ & $3(19)$ & \\
\hline Radiotherapy, chemotherapy, hormone therapy & $2(17)$ & $1(6)$ & \\
\hline $\begin{array}{l}\text { Radiotherapy, chemotherapy, hormone therapy, } \\
\text { immunotherapy }\end{array}$ & $1(8)$ & - & \\
\hline \multicolumn{3}{|l|}{ Participation in rehabilitation, $n(\%)$} & \multirow{3}{*}{ NS } \\
\hline Yes & $9(75)$ & $10(63)$ & \\
\hline No & $3(25)$ & $6(37)$ & \\
\hline
\end{tabular}

${ }^{*}$ Category included both women after breast conserving surgery and after mastectomy

\section{Statistical analysis}

Data were analysed with the use of statistical package SPSS (version 2.1). Since distributions were significantly different from normal, for within- and betweengroup comparisons non-parametrical tests were used - Mann-Whitney and Wilcoxon, accordingly. $\chi^{2}$ contingency index was calculated to estimate the differences in distributions of nominal variables. $P$ values lower than 0.05 indicated statistically significant results.

\section{Results}

Table II presents means and standard deviations in the questionnaire scales achieved by exercising and non-exercising women, before and after the programme.

To assess yoga's impact on functioning of exercising women, the results from scales differentiating participants in the first stage were not taken into account in further inferring (it referred to Nausea and vomiting and Pain). We analysed the results only from these scales that did not differentiate participants in the first stage but there occurred differences after the programme (Table III). Therefore, we analysed betweengroup comparisons of: General health status and quality of life, Physical and Social functioning, Role functioning, Dyspnoea, Future prospects and Arm and Breast symptoms. The differences occurring in the second measurement revealed significantly higher indices of General health status and quality of life, Physical and Social functioning, Role functioning and Future prospects, and significantly lower indices of Dyspnoea, Arm and Breast symptoms and Fatigue (borderline significance $p=0.059$ ) in the experimental group.

Within-group comparisons revealed differences in the results obtained in the two measurements. In the experimental group, the index of General health status and quality of life significantly increased $(p=0.048)$ and Arm symptoms significantly declined $(p=0.046)$ after the programme. The decrease in the Dyspnoea index in this group in the second measurement was on the borderline of statistical significance $(p=0.059)$. In 
Tab. II. Means, standard deviations and medians of the questionnaire scales in both groups before and after the programme

\begin{tabular}{|c|c|c|c|c|c|c|c|c|}
\hline & \multicolumn{4}{|c|}{ Experimental group } & \multicolumn{4}{|c|}{ Control group } \\
\hline & \multicolumn{2}{|c|}{ First measurement } & \multicolumn{2}{|c|}{$\begin{array}{c}\text { Second } \\
\text { measurement }\end{array}$} & \multicolumn{2}{|c|}{ First measurement } & \multicolumn{2}{|c|}{$\begin{array}{c}\text { Second } \\
\text { measurement }\end{array}$} \\
\hline & $M(S D)$ & $\mathrm{Me}$ & $M(S D)$ & Me & $M(S D)$ & $\mathrm{Me}$ & $M(S D)$ & Me \\
\hline \multicolumn{9}{|c|}{ Basic module QLQ-C30 - functioning scales } \\
\hline $\begin{array}{l}\text { General health status and quality } \\
\text { of life }\end{array}$ & $61.1(12.5)$ & 58.3 & $72.2(14.8)$ & 75 & $56.3(20.3)$ & 54.2 & $55.6(23.5)$ & 50 \\
\hline Physical functioning & $84.2(11.8)$ & 81.7 & $85.0(13.4)$ & 86.7 & $71.1(17.2)$ & 73.3 & $69.5(17.1)$ & 76.7 \\
\hline Role functioning & $90.3(13.2)$ & 100 & $86.1(25.5)$ & 100 & $80.2(26.7)$ & 83.3 & $68.8(27.1)$ & 75 \\
\hline Emotional functioning & $58.3(23.8)$ & 58.3 & $64.6(21.7)$ & 66.7 & $51.4(30.7)$ & 54.2 & $51.7(29.0)$ & 50 \\
\hline Cognitive functioning & $68.1(28.8)$ & 75 & $75.0(21.9)$ & 66.7 & $56.3(32.1)$ & 50 & $61.5(29.0)$ & 66.7 \\
\hline Social functioning & $81.9(20.7)$ & 83.3 & $83.3(17.4)$ & 83.3 & $70.8(26.9)$ & 66.7 & $63.5(27.4)$ & 66.7 \\
\hline \multicolumn{9}{|c|}{ Basic module QLQ-C30 - symptoms scales } \\
\hline Fatigue & $32.4(18.0)$ & 33.3 & $31.5(18.2)$ & 33.3 & $43.8(20.9)$ & 38.9 & $48.3(23.4)$ & 44.4 \\
\hline Nausea and vomiting & $1.4(4.8)$ & 0 & $1.4(4.8)$ & 0 & $30.0(44.2)$ & 0 & $16.7(28.5)$ & 0 \\
\hline Pain & $13.9(12.0)$ & 16.7 & $25.0(31.4)$ & 16.7 & $41.7(25.8)$ & 33.3 & $39.6(25.7)$ & 33.3 \\
\hline Dyspnoea & $19.4(22.3)$ & 16.7 & $5.6(13.0)$ & 0 & $27.1(25.0)$ & 33.3 & $29.2(31.9)$ & 33.3 \\
\hline Insomnia & $44.4(43.4)$ & 33.3 & $41.7(32.2)$ & 33.3 & $52.1(40.3)$ & 50 & $52.1(27.1)$ & 66.7 \\
\hline Appetite loss & $5.6(13.0)$ & 0 & $8.3(20.7)$ & 0 & $18.8(34.4)$ & 0 & $18.8(21.0)$ & 16.7 \\
\hline Constipation & $19.4(30.0)$ & 0 & $16.7(22.5)$ & 0 & $22.2(37.1)$ & 0 & $35.4(39.4)$ & 16.7 \\
\hline Diarrhoea & $5.6(13.0)$ & 0 & $2.8(9.6)$ & 0 & $8.3(14.9)$ & 0 & $10.4(20.1)$ & 0 \\
\hline Financial difficulties & $30.6(38.8)$ & 16.7 & $16.7(22.5)$ & 0 & $47.9(29.7)$ & 33.3 & 37.5 (31.9) & 33.3 \\
\hline \multicolumn{9}{|c|}{ Breast cancer module QLQ-BR23 - functioning scales } \\
\hline Body image & $69.4(21.1)$ & 66.7 & $76.2(18.9)$ & 79.2 & $61.5(31.8)$ & 66.7 & $59.9(35.5)$ & 66.7 \\
\hline Sexual functioning* & $22.2(20.5)$ & 25 & $26.4(20.7)$ & 33.3 & $24.4(28.8)$ & 16.7 & $20.0(28.3)$ & 0 \\
\hline Sexual enjoyment* & $38.1(23.0)$ & 33.3 & $57.1(31.7)$ & 33.3 & $83.3(18.3)$ & 83.3 & $75.0(16.7)$ & 66.7 \\
\hline Future prospects & $55.6(32.8)$ & 66.7 & $61.1(27.8)$ & 66.7 & $39.6(30.4)$ & 50 & $35.4(31.0)$ & 33.3 \\
\hline \multicolumn{9}{|c|}{ Breast cancer scales QLQ-BR23 - symptoms scales } \\
\hline Systematic therapy side effects & $18.3(12.8)$ & 14.3 & $19.4(14.0)$ & 19 & $27.9(15.0)$ & 28.6 & $31.3(16.7)$ & 31 \\
\hline Breast symptoms & $7.6(7.5)$ & 8.3 & $4.9(5.6)$ & 4.2 & $22.9(28.9)$ & 8.3 & $31.6(32.7)$ & 16.7 \\
\hline Arm symptoms & $25.9(17.9)$ & 27.8 & $18.5(17.3)$ & 16.7 & $42.4(24.1)$ & 44.4 & $43.8(26.4)$ & 44.4 \\
\hline Upset by hair loss* & $100.0(12.8)$ & 100 & $41.7(16.7)$ & 33.3 & $37.5(27.8)$ & 33.3 & $42.9(31.7)$ & 33.3 \\
\hline
\end{tabular}

${ }^{*}$ Due to a small number of participants who answered the questions from this scale, the result was not considered in interpretation

the control group, after 10 weeks the results in Social functioning were significantly lower than in the first measurement and we also observed a significant decrease in the Role functioning index $(p=0.045)$.

\section{Discussion}

Women who took part in a 10 -week rehabilitation programme based on the yoga method experienced positive changes concerning general quality of life, physical and social functioning as well as reduction of difficulties in performing everyday activities. After the programme, women who exercised reported that they suffered less from dyspnoea and discomfort in the arm and breast on the operated side (decreased pain, swelling, sensitivity in the breast area, reduction of pain in the arm or difficulties in raising the arm). They also had better future prospects - they worried less about their 
Tab. III. Mean ranks and results of between-group comparisons of the results from questionnaire scales (Mann-Whitney test)

\begin{tabular}{|c|c|c|c|c|c|c|}
\hline & \multicolumn{3}{|c|}{ First measurement } & \multicolumn{3}{|c|}{ Second measurement } \\
\hline & $\begin{array}{l}\text { Experimental } \\
\text { group }\end{array}$ & $\begin{array}{l}\text { Control } \\
\text { group }\end{array}$ & $p$ & $\begin{array}{l}\text { Experimental } \\
\text { group }\end{array}$ & $\begin{array}{l}\text { Control } \\
\text { group }\end{array}$ & $p$ \\
\hline \multicolumn{7}{|l|}{ Basic module QLQ-C30 - functioning scales } \\
\hline General health status and quality of life & 15.9 & 13.5 & NS & 17.6 & 11.1 & 0.033 \\
\hline Physical functioning & 17.6 & 12.2 & NS & 19.3 & 10.9 & 0.007 \\
\hline Role functioning & 16.1 & 13.3 & NS & 18.1 & 11.8 & 0.035 \\
\hline Emotional functioning & 15.5 & 13.8 & NS & 16.2 & 13.2 & NS \\
\hline Cognitive functioning & 16.4 & 13.1 & NS & 16.5 & 13.0 & NS \\
\hline Social functioning & 16.6 & 12.9 & NS & 18.0 & 11.8 & 0.042 \\
\hline \multicolumn{7}{|l|}{ Basic module QLQ-C30 - symptoms scales } \\
\hline Fatigue & 11.8 & 16.5 & NS & 11.2 & 17.0 & 0.059 \\
\hline Nausea and vomiting & 11.0 & 16.4 & 0.027 & 11.5 & 16.7 & 0.038 \\
\hline Pain & 8.9 & 18.7 & 0.001 & 11.4 & 16.8 & NS \\
\hline Dyspnoea & 13.2 & 15.5 & NS & 11.0 & 17.1 & 0.025 \\
\hline Insomnia & 13.7 & 15.1 & NS & 12.9 & 15.7 & NS \\
\hline Appetite loss & 13.2 & 15.5 & NS & 12.1 & 16.3 & NS \\
\hline Constipation & 13.9 & 14.1 & NS & 12.6 & 15.9 & NS \\
\hline Diarrhoea & 13.8 & 15.0 & NS & 13.1 & 15.5 & NS \\
\hline Financial difficulties & 11.8 & 16.5 & NS & 11.5 & 16.8 & NS \\
\hline \multicolumn{7}{|c|}{ Breast cancer module QLQ-BR23 - functioning scales } \\
\hline Body image & 15.2 & 14.0 & NS & 16.3 & 13.2 & NS \\
\hline Sexual functioning* & 14.3 & 13.8 & NS & 15.7 & 12.7 & NS \\
\hline Sexual enjoyment* & 4.4 & 10.0 & 0.007 & 5.2 & 7.4 & NS \\
\hline Future prospects & 16.7 & 12.9 & NS & 18.0 & 11.9 & 0.037 \\
\hline \multicolumn{7}{|c|}{ Breast cancer scales QLQ-BR23 - symptoms scales } \\
\hline Systematic therapy side effects & 11.3 & 16.9 & NS & 11.3 & 16.9 & NS \\
\hline Breast symptoms & 12.6 & 15.9 & NS & 9.3 & 18.4 & 0.003 \\
\hline Arm symptoms & 11.3 & 16.9 & NS & 9.8 & 18.0 & 0.008 \\
\hline Upset by hair loss* & 8.5 & 4.6 & NS & 6.1 & 5.9 & NS \\
\hline
\end{tabular}

health in the future. Reduction of perceived fatigue among exercising women as compared to non-exercising ones in the second measurement was on the borderline of statistical significance. During informal conversations, the participants expressed their satisfaction with the participation in the yoga programme.

We assume that the observed changes - subjective improvement as regards physical functioning, reduction of dyspnoea and discomfort in the area of the operated breast and arm of the operated side and fatigue in particular - resulted from the participation in the yoga programme. This corresponds to previous findings that documented the impact of yoga practice on physical functioning - improvement of physical fitness, flexibility of joints or muscles stamina [26].

Dyspnoea is one of the common problems related to cancer. Unfortunately, extant research lacks studies on the influence of yoga on the functioning of the respiratory system among oncological patients. We based our conclusion, that participation in the yoga programme affected the reduction of this aggravating consequence of this disease, on the research conducted on patients 
suffering from chronic respiratory diseases (asthma, chronic bronchitis, chronic obstructive lung disease). That research revealed a significant influence of exercises based on asanas and pranayama on improvement of the respiratory system functioning, reduction of dyspnoea and the necessity to use medicines [27, 28]. Therefore, the reduction of dyspnoea indicated in our experimental group could be a result of the technique of controlling breath (pranayama) and relaxation exercises practicing during the programme.

Participants of the yoga programme perceived a decrease in discomfort in the arm and breast on the operated side. Weakness or loss of efficiency sensed in the arm, especially when the arm is of the dominant side, constitutes an obstacle to perform work or everyday activities. Thus, such symptoms negatively influence the quality of life of women after breast surgery. Considering rehabilitation, the results indicated effectiveness of the exercises based on asanas in strengthening arms' muscles, improving the flexibility of the shoulder girdle, stretching the areas where a post-operative cicatrix occurred. The improvement of these dimensions of patients' quality of life can be also explained with the occurrence of another positive consequence of exercises - namely the reduction of difficulties in everyday functioning (performing daily activities, realising hobbies).

Fatigue constituted another measured consequence of cancer and its treatment that changed after the participation in the yoga programme. Among exercising women, a subjective sense of fatigue decreased. Basing on previous findings stating that yoga reduces fatigue [20], we believe a similar phenomenon occurred in our participants, what constitutes another positive result of the proposed yoga programme.

We assume that the improvement in social functioning, especially as regards socializing resulted from the fact that weekly meetings became also a source of social activity for the participants. Additionally, these meetings involved women in a similar health situation what provided them with support and understanding [18]. This corresponds to another study that confirmed the impact of yoga classes on participants' social wellbeing [7]. Whereas, we observed a significant worsening as regards social and everyday functioning between the first and second measurement in non-exercising women.

Exercising women reported that they worried less about their health in the future as compared to the time before the programme. Searching for an explanation to such finding, it is worth turning to yoga's origins. Yoga is a practice of uniting body and mind and its aim is the fullest possible experience of one's condition and state of mind, here and now. It increases mindfulness, which is described as the state of being attentive and aware of what is taking place at present [29]. Being mindful is an intentional process of focusing one's attention on what appears in consciousness at the present moment. Concentrating on the present decreases anxiety and depression, helps to achieve the state of relaxation. The ability of being 'here and now' helps not to think forward - in the case of insecure future of people with diagnosed cancer, it prevents excessive anxiety. Hence, the fact that the exercising women reported to worry less about their health after the programme could result from the mental work performed and practised during yoga classes.

We could not confirm the hypotheses that exercising yoga would impact emotional functioning and body image. Lack of such differences may be that we did not control factors that could regulate emotional functioning of the participants. Moreover, women under the study (both those exercising and non-exercising) got lower scores in emotional functioning and body image as compared to the reference values provided by EORTC [30] (analysis not shown). A longer exercising programme could possibly reveal changes in the body perception (e.g. visible weight loss or firming of the body).

A small sample on the one hand may be considered as a limitation but, on the other hand, a small number of exercising participants was optimal to provide them with sufficient space needed to perform exercises and the instructor could pay necessary attention to each woman, taking care of correct performance of asanas. The study was not randomized - all women who volunteered to take part in yoga classes were included in the experimental group. Considering the study's pioneering nature in Poland and the need to encourage women after breast surgery to engage in physical activity, it was important to allow all willing women to participate in the yoga programme. However, we believe, that further research on this issue should involve randomization. The above research also lacked an additional measurement of the studied variables some time after the programme ended. With such data, controlling of other variables, it would be possible to assess whether the observed changes resulted from the exercises and how long the effects pertained.

\section{Conclusions}

Considering our results and referring to the previous research, we believe that rehabilitation of patients after breast cancer surgery with the use of yoga constitutes a safe and effective form of activity improving their quality of life. Therefore, we recommend establishing similar exercising rehabilitation programmes dedicated to every woman after breast surgery as well as further assessment of their effectiveness. In Western countries, yoga is a well-acknowledged method of physical and mental regeneration while in Poland by some it is still treated with distrust and caution raised by its unknown and thus, misunderstood cultural and religious origin. 
However, this aspect is not manifested during yoga practice, its fundamental aim is to practice asanas and ability to relax.

We recommend further research considering the impact of yoga classes on functioning of women after breast cancer surgery in Poland, taking different stages of post-operational rehabilitation into consideration. The real availability of such form of rehabilitation is also worth verifying, so as to make our recommendations possible to implement. Yoga is one of rather expensive forms of recreation and the current groups division considers mainly the level of advancement, physical fitness or some of health limitations experienced by participants (glaucoma, spinal curvature or degeneration, discopathy, etc.). The classes dedicated exclusively to people with their limitations resulting from surgical interventions are rare. We would like more such groups to occur and yoga classes to be placed on the list of reimbursable benefits for women after breast surgery, what would significantly increase their availability.

\section{Disclosure}

\section{Authors report no conflicts of interest.}

\section{References}

1. Trentham-Dietz A, Sprague Bl, Klein R, et al. Health-related quality of life before and after a breast cancer diagnosis. Breast Cancer Res Treat 2008; 109: 379-387.

2. Montazeri A, Vahdaninia M, Harirchi I, et al. Quality of life in patients with breast cancer before and after diagnosis: an eighteen months follow-up study. BMC Cancer 2008; 8: 330

3. Didkowska J, Wojciechowska U, Zatoński W. Nowotwory złośliwe w Polsce w 2011 roku. Krajowy Rejestr Nowotworów, Zakład Epidemiologii i Prewencji Nowotworów, Warszawa 2013.

4. Didkowska J, Zatoński W, Wojciechowska U, et al. Prognozy zachorowalności i umieralności na nowotwory złośliwe w Polsce do 2025 roku. Centrum Onkologii - Instytut im. Marii Skłodowskiej-Curie, Warszawa 2009.

5. Zatoński W, Mańczuk M, Sulkowska U. Wyrównywanie różnic w zdrowiu między krajami Unii Europejskiej. Zakład Epidemiologii i Prewencji Nowotworów, Centrum Onkologii - Instytut im. Marii SkłodowskiejCurie, Warszawa 2011.

6. Nowakowska C, Fellmann B, Pasek T, et al. Ocena wpływu ćwiczeń relaksowo-koncentrujących wzorowanych na jodze u pacjentów z psychogennymi zaburzeniami psychicznymi. Psychiatr Pol 1982; 16: 365-370.

7. Cramer $\mathrm{H}$, Lange $\mathrm{S}$, Klose $\mathrm{P}$, et al. Yoga For breast cancer patients and survivors: a systematic review and meta-analysis. BMC Cancer 2012; 12: 412.

8. Bąk M, Cieśla S. Ocena zaburzeń postawy ciała kobiet po radykalnej amputacji z jednoczasową rekonstrukcją piersi. Fizjoterapia 2009; 17: 30-37.

9. Bąk M. Postawa ciała w płaszczyźnie strzałkowej kobiet po mastektomii aktywnie uczestniczących w rehabilitacji ruchowej. Fizjoterapia 2008; 16: 35-43.
10. Vojáčková N, Fialová J, Hercogová J. Management of lymphedema. Dermatol Ther 2012; 25: 352-357.

11. Galantino ML, Greene L, Archetto B, et al. A qualitative exploration of the impact of yoga on breast cancer survivors with aromatase inhibitorassociated arthralgias. J Science Healing 2012; 8: 40-47.

12. Danhauer SC, Tooze JA, Farmer DF, et al. Restorative yoga for women with ovarian or breast cancer: findings from a pilot study. J Soc Integr Oncol 2008; 6: 47-58.

13. Levine AS, Balk JL. Pilot study of yoga for breast cancer survivors with poor quality of life. Complement Ther Clin Pract 2012; 18: 241-245.

14. Rao MR, Raghuram N, Nagendra HR, et al. Anxiolytic effects of a yoga programme in early breast cancer patients undergoing conventional treatment: a randomized controlled trial. Complement Ther Med 2009; 17: $1-8$.

15. Raghavendra RM, Nagarathna R, Nagendra HR, et al. Effects of an integrated yoga programme on chemotherapy-induced nausea and emesis in breast cancer patients. Eur J Cancer Care 2007; 16: 462-474.

16. Danhauer SC, Mihalko SL, Russell GB, et al. Restorative yoga for women with breast cancer: findings from a randomized pilot study. Psychooncology 2009; 18: 360-368.

17. Speed-Andrews AE, Stevinson C, Belanger LJ, et al. Predictors of adherence to an iyengar yoga programme in breast cancer survivors. Int J Yoga 2012; 5: 3-9.

18. Thomas R, Shaw RM. Yoga for women living with breast cancer-related arm morbidity: findings from an exploratory study. Int J Yoga Therap 2011; 21: 39-48.

19. Carson JW, Carson KM, Porter LS, et al. Yoga for women with metastatic breast cancer: results from a pilot study. J Pain Symptom Manage 2007; 33: 331-341.

20. Cramer $\mathrm{H}$, Lange $\mathrm{S}$, Klose $\mathrm{P}$, et al. Can yoga improve fatigue in breast cancer patients? A systematic review. Acta Oncol 2012; 51: 559-560.

21. Culos-Reed SN, Carlson LE, Daroux LM, et al. A pilot study of yoga for breast cancer survivors: physical and psychological benefits. Psychooncology 2006; 15: 891-897.

22. Lin K-Y, Hu Y-T, Chang K-J, et al. Effects of yoga on psychological health, quality of life, and physical health of patients with cancer: a meta-analysis. Evidence-Based Complemen Altern Med 2011; 2011: 1-12.

23. Harder H, Parlour L, Jenkins V. Randomised controlled trials of yoga interventions for women with breast cancer: a systematic literature review. Support Care Cancer 2012; 20: 3055-3064.

24. Aaronson NK, Ahmedzai S, Bergman B, et al. The European Organization for Research and Treatment of Cancer QLQ-C30: a quality-of-life instrument for use in international clinical trials in oncology. J Natl Cancer Inst 1993; 85: 365-376.

25. Fayers P, Aaronson N, Bjordal K, et al. EORTC-QLQ-C30 Scoring Manual. $3^{\text {rd }}$ ed. European Organisation for Research and Treatment of Cancer, Brussels 2001.

26. Van Puymbroeck M, Schmid A, Shinew KJ, et al. Influence of hatha yoga on physical activity constraints, physical fitness, and body image of breast cancer survivors: a pilot study. Int J Yoga Ther 2011; 21: 49-60.

27. Raub JA. Psychophysiologic effects of hatha yoga on musculoskeletal and cardiopulmonary function: a literature review. J Alt Compl Med 2002; 8: 797-812.

28. Santana M-J, Mirus J, Loadman M, et al. An assessment of the effects of iyengar yoga practice on the health-related quality of life of patients with chronic respiratory diseases: a pilot study. Can Resp J 2012; 20: E17-23.

29. Brown KW, Ryan RM. The Benefits of being present: mindfulness and its role in psychological well-being. J Pers Soc Psychol 2003; 84: 822-848.

30. Scott NW, Fayers PM, Aaronson NK, et al. EORTC QLQ-C30 Reference Manual 2008. EORTC Quality of Life Group, Brussels 2008. 